\title{
Chromium and selenium-enriched yeast for castrated finishing pigs: effects on performance and carcass characteristics
}

\section{Cromo e selênio leveduras para suínos castrados em terminação: efeitos sobre o desempenho e características de carcaça}

\author{
João Garcia Caramori Júnior'; Charles Kiefer²; Eduardo Viana Ferreira ${ }^{3}$; \\ Bruno Serpa Vieira $^{4 *}$; Henrique Carvalho Oliveira ${ }^{5}$; Camila Mendonça Silva ${ }^{6}$; \\ Rodrigo Caetano Abreu ${ }^{6}$; Uanderson Veríssimo de Luna ${ }^{4}$
}

\begin{abstract}
To evaluate the effect of organic chromium $(\mathrm{Cr})$ and selenium $(\mathrm{Se})$ supplementation on performance and carcass characteristics of finishing pigs, 300 castrated males were distributed in a randomized block design with three treatments and five replications of 20 pigs each. Treatments consisted of different diets, formulated to reach or exceed Rostagno et al. (2011) nutritional requirements, as follows: 1) control basal diet without organic $\mathrm{Cr}$ and Se supplementation from 70 to $130 \mathrm{~kg}$ of body weight; 2) $\mathrm{CrSe} 70$ basal diet supplemented with $0.8 \mathrm{mg} \mathrm{kg}^{-1}$ of Cr- and $0.6 \mathrm{mg} \mathrm{kg}^{-1}$ of Se-enriched yeast from 70 to $130 \mathrm{~kg}$ of body weight; 3) CrSe100 - basal diet without organic $\mathrm{Cr}$ and Se supplementation from 70 to $100 \mathrm{~kg}$ of body weight followed by basal diet supplemented with $0.8 \mathrm{mg} \mathrm{kg}^{-1}$ of Cr- and $0.6 \mathrm{mg} \mathrm{kg}^{-1}$ of Se-enriched yeast from 100 to $130 \mathrm{~kg}$ of body weight. Performance was evaluated by measuring body weight, daily weight gain, daily feed intake and feed conversion ratio. At the end of experimental period, pigs were sacrificed and lean meat percentage, longissimus dorsi muscle depth, back fat thickness, and carcass bonus index were determined using prediction equations generated by the software Hennessy System GP4 after carcass scanning with an electronic probe. Data were submitted to one-way ANOVA and in case of significant differences $(P \leq 0.05)$, means were compared by SNK multiple-range test. Daily feed intake $(P=0.008)$ and feed conversion ratio $(P=0.004)$ decreased for pigs supplemented with $\mathrm{Cr}$ - and Se-enriched yeast from 70 to $100 \mathrm{~kg}$ of body weight. Otherwise, pigs supplemented between 100 and $130 \mathrm{~kg}$ of body weight increased $(P=0.032)$ daily feed intake in comparison to the control group. Regarding carcass characteristics, $\mathrm{Cr}$ - and Se-enriched yeast supplementation increased $(P=$ 0.019) longissimus dorsi muscle depth in both $\mathrm{CrSe} 70$ and $\mathrm{CrSe} 100$ treatments. In conclusion, dietary supplementation of Cr- and Se-enriched yeast for castrated male pigs between 70 and $130 \mathrm{~kg}$ of body weight increases longissimus dorsi muscle depth in carcass without affecting final body weight or daily weight gain of the animals.
\end{abstract}

Key words: Feed additive. Organic minerals. Longissimus dorsi. Weight gain.

1 Prof., Universidade Federal de Mato Grosso, UFMT, Cuiabá, MT, Brasil. E-mail: caramori.ufmt@gmail.com

2 Prof., Universidade Federal de Mato Grosso do Sul, UFMS, Campo Grande, MS, Brasil. E-mail: charles.kiefer@ufms.br

3 Discente, Curso de Mestrado, Programa de Pós-Graduação em Ciência Animal, UFMT, Cuiabá, MT, Brasil. E-mail: eduardovferreira@gmail.com

4 Discentes, Curso de Doutorado, Programa de Pós-Graduação em Ciência Animal, UFMT, Cuiabá, MT, Brasil. E-mail: vieirabs@ hotmail.com; uandersonluna@hotmail.com

5 Discente, Curso de Graduação em Zootecnia, UFMT, Cuiabá, MT, Brasil. E-mail: hcozootecnia@gmail.com

6 Discentes, Curso de Doutorado, Programa de Pós-Graduação em Ciência Animal, UFMS, Campo Grande, MS, Brasil. E-mail: camillamsazoo@gmail.com; rodrigo.caetano_8@hotmail.com

* Author for correspondence 


\section{Resumo}

Avaliou-se o efeito da suplementação de cromo $(\mathrm{Cr})$ e selênio (Se) orgânico na dieta de suínos de 70 a $130 \mathrm{~kg}$ de peso vivo sobre o desempenho e características de carcaça. Foram utilizados 300 suínos machos castrados, distribuídos em um delineamento em blocos casualizados com três tratamentos e cinco repetições de 20 animais. Os tratamentos consistiram em diferentes dietas, formuladas conforme as exigências nutricionais estabelecidas por Rostagno et al. (2011), como segue: 1) controle - dieta basal sem inclusão de $\mathrm{Cr}$ e Se orgânicos de 70 a $130 \mathrm{~kg}$ de peso vivo; 2) $\mathrm{CrSe} 70$ - dieta basal com inclusão de $0,8 \mathrm{mg} \mathrm{kg}^{-1}$ de $\mathrm{Cr}$ e $0,6 \mathrm{mg} \mathrm{kg}^{-1}$ de Se leveduras de 70 a $130 \mathrm{~kg}$ de peso vivo; 3) $\mathrm{CrSe} 100$ - dieta basal sem inclusão de $\mathrm{Cr}$ e Se orgânicos de 70 a $100 \mathrm{~kg}$ de peso vivo, seguida de dieta basal com inclusão de $0,8 \mathrm{mg} \mathrm{kg}^{-1}$ de $\mathrm{Cr}$ e $0,6 \mathrm{mg} \mathrm{kg}^{1}$ de Se leveduras de 100 a $130 \mathrm{~kg}$ de peso vivo. $\mathrm{O}$ desempenho foi avaliado por meio dos parâmetros peso vivo, ganho de peso diário, consumo de ração diário e conversão alimentar. Ao final do período experimental, todos os animais foram abatidos para determinação da percentagem de carne magra, profundidade do músculo longissimus dorsi, espessura de toucinho e índice de bonificação das carcaças por meio de equações de predição geradas com auxílio de sonda eletrônica e software Hennessy System GP4 para tipificação de carcaças suínas. Os dados foram submetidos à análise de variância e, em caso de diferença significativa $(P \leq 0,05)$, as médias foram comparadas pelo teste SNK. Observou se redução $(P=0,008)$ no consumo de ração e melhora $(P=0,004)$ na conversão alimentar dos suínos suplementados com $\mathrm{Cr}$ e Se leveduras entre 70 e 100 $\mathrm{kg}$ de peso vivo. De modo contrário, a suplementação de $\mathrm{Cr}$ e Se leveduras de 100 a $130 \mathrm{~kg}$ de peso vivo aumentou $(P=0,032)$ o consumo de ração dos animais. Em relação às características de carcaça, maior $(P=0,019)$ profundidade do músculo longissimus dorsi foi observada independente do período de suplementação. Conclui-se que a suplementação de $\mathrm{Cr}$ e Se leveduras em suínos machos castrados de 70 a $130 \mathrm{~kg}$ de peso vivo aumenta a profundidade do músculo longissimus dorsi sem alterar o peso vivo final e o ganho de peso diário dos animais.

Palavras-chave: Aditivo. Minerais orgânicos. Longissimus dorsi. Ganho de peso.

\section{Introduction}

Different feed additives have been investigated for improving swine performance, reducing fat deposition and increasing carcass lean meat percentage (BRUMATTI; KIEFER, 2010). Among them, ractopamine has received great attention because of its energy-repartitioning effect, which favors performance and carcass characteristics during the finishing phase, reducing fat and enhancing lean tissue deposition (KIEFER et al., 2009). However, the use of ractopamine has been questioned in different countries because of its possible effects on the health of human consumers, thus becoming a food safety issue (CENTNER et al., 2014). Some researchers speculate that organic minerals, such as chromium $(\mathrm{Cr})$ and selenium (Se), could act like ractopamine and modify carcass characteristics of animals (SAKOMURA et al.,
2014). Nevertheless, the effect of these minerals on performance and carcass characteristics of swine are still inconsistent and inconclusive (CHIBA, 2013).

According to Lien et al. (2001) and Peres et al. (2014), the positive effects of organic $\mathrm{Cr}$ on performance and carcass composition of finishing pigs have already been demonstrated. Conversely, no effect of organic Cr supplementation for swine was described by Matthews et al. (2001, 2005). A similar situation occurred with organic Se for pigs: positive effects on performance and carcass characteristics were described in some trials (JANG et al., 2010; MARTINEZ-GOMEZ et al., 2012), but a lack of effect on these characteristics was described in others (STUPKA et al., 2012; CAMPOS, 2013).

Considering the discrepancy among information regarding the effects of organic $\mathrm{Cr}$ and $\mathrm{Se}$ supplementation for swine, the objective of this 
research was to determine if organic $\mathrm{Cr}$ and $\mathrm{Se}$ supplementation affects performance and carcass characteristics of finishing pigs.

\section{Materials and Methods}

\section{General procedures}

One trial was conducted in a commercial pig farm located in the Midwest region of Brazil. All experimental procedures were previously approved by the Committee of Ethics in the Use of Animals of the Federal University of Mato Grosso do Sul (process \# 840/2017). Pigs were managed according to commercial practices and were raised in an opensided house provided with fans and sprinklers for environment control. Temperature was checked constantly and recorded once per day.

A total of 300 commercial-hybrid male pigs with similar genetic backgrounds and average weight $(66.17 \pm 1.62 \mathrm{~kg})$ were divided into groups of 20 animals and allocated in 15 concrete floor pens equipped with semi automatic feeders and nipple drinkers. Each pen was considered a replication in a randomized block design with three treatments and five replications. Treatments consisted of different diets, provided ad libitum and in mashed form, according to the following scheme: 1) control - basal diet without organic $\mathrm{Cr}$ and Se supplementation from 70 to $130 \mathrm{~kg}$ of body weight (BW);2) CrSe70 - basal diet supplemented with Cr- and Se-enriched yeast from 70 to $130 \mathrm{~kg}$ of BW; 3) CrSe100 - basal diet without organic $\mathrm{Cr}$ and Se supplementation from 70 to $100 \mathrm{~kg}$ of BW, but supplemented with $\mathrm{Cr}$ - and Seenriched yeast from 100 to $130 \mathrm{~kg}$ of BW. The basal diet was based on corn, soybean meal and sorgum, and it was formulated to reach or exceed nutritional requirements outlined by Rostagno et al. (2011) (Table 1). Organic $\mathrm{Cr}$ and Se were included replacing filler, at 0.8 and $0.6 \mathrm{mg} \mathrm{kg}-1$ of feed, respectively. Their source was a commercial additive composed of yeast (Saccharomyces cerevisiae) enriched with $\mathrm{Cr}$, Se, dried brewer's yeast, Schizochitrium sp., ascorbic acid, and Aspergillus niger. 
Table 1. Basal diet composition (as-fed basis).

\begin{tabular}{lcc}
\hline Ingredients (\%) & $70-100 \mathrm{~kg}$ & $100-130 \mathrm{~kg}$ \\
\hline Corn (7.88) & 43.829 & 50.757 \\
Soyben meal (46\%) & 21.495 & 14.496 \\
Sorgum & 29.993 & 29.993 \\
Meat and bone meal (41\%) & 2.999 & 2.999 \\
Vitamin-mineral premix ${ }^{1}$ & 1.500 & 1.500 \\
L-Lys & 0.140 & 0.200 \\
L-Thr & 0.020 & 0.030 \\
Filler or Cr+Se supplement & 0.050 & 0.050 \\
\hline Calculated composition (\%, unless otherwise indicated) $)^{2}$ & & 14.80 \\
Crude protein & 17.42 & 3,330 \\
Metabolizable enregy (Kcal/kg) & 3,330 & 0.460 \\
Calcium & 0.480 & 0.250 \\
Available phosphorus & 0.260 & 0.140 \\
Sodium & 0.160 & 0.710 \\
Digestible Lys & 0.830 & 0.410 \\
Digestible Met+Cys & 0.470 & 0.490 \\
Digestible Thr & 0.570 & 0.140 \\
Digestible Trp & 0.200 & 0.620 \\
Digestible Val & 0.730 & \\
\hline
\end{tabular}

${ }^{1}$ Provided in $1 \mathrm{~kg}$ of product, 70-100 kg: coline $37.5 \mathrm{~g}$, vit. A 1,625,000 IU, vit. $\mathrm{D}_{3}$ 400,000 IU, vit. E 7,500 IU, vit. K, $750 \mathrm{mg}$, vit. $B_{1} 550 \mathrm{mg}$, vit. $B_{2} 1,375 \mathrm{mg}$, vit. $B_{6} 500 \mathrm{mg}$, vit. $B_{12} 5,000 \mathrm{mg}$, niacin 5,000 mg, pantothenic acid 2,300 mg, folic acid $125 \mathrm{mg}$, biotin 7.5 mg, Fe 25 g, Cu 3,750 mg, Mn 12.5 g, Zn 31.25 g, I 250 mg; Se 75 mg. 100-130 kg: coline 100 g, vit. A 6,000,000 IU, vit. $\mathrm{D}_{3} 1,000,000 \mathrm{IU}$, vit. E $12,000 \mathrm{IU}$; vit. $\mathrm{K}_{3} 1.5 \mathrm{~g}$, vit. $\mathrm{B}_{1} 0.5 \mathrm{~g}$, vit. $\mathrm{B}_{2} 2.6 \mathrm{~g}$, vit. $\mathrm{B}_{6} 0.7 \mathrm{~g}$, vit. $\mathrm{B}_{12} 0.015 \mathrm{~g}$, pantothenic acid $10 \mathrm{~g}$, folic acid $0.2 \mathrm{~g}$, biotin $0.05 \mathrm{~g}$, nicotinic acid $22 \mathrm{~g}$, Fe $100 \mathrm{~g}, \mathrm{Cu} 10 \mathrm{~g}$, Mn $30 \mathrm{~g}$, Zn $100 \mathrm{~g}$, I $1 \mathrm{~g}$, Se $0.3 \mathrm{~g}$, Co 0.2 g.

${ }^{2}$ Based on ingredient composition by Rostagno et al. (2011).

\section{Performance and carcass characteristics}

Pigs were individually weighed three times during the experimental period: in the beginning of the trial at approximately $70 \mathrm{~kg}(66.17 \pm 1.62$ $\mathrm{kg}$ ), when they reached approximately $100 \mathrm{~kg}$ $(104.35 \pm 2.40 \mathrm{~kg})$ and at the end of the experiment at approximately $130 \mathrm{~kg}(129.67 \pm 2.43 \mathrm{~kg})$. Immediately before the pigs were weighed, average feed intake was determined by subtracting feed leftovers from the total amount supplied for each pen. Mortality was checked daily and was used to correct feed conversion calculations.
After the last weighing, pigs were fasted for $12 \mathrm{~h}$ before being sacrificed in a commercial processing plant according to the rules established by the Ministry of Agriculture, Livestock and Food Supply in Brazil (BRASIL, 1995). In short, animals were rendered insensible by electrical stunning and terminated via exsanguination by laceration of the great vessels of the neck. Carcasses were then scalded, dehaired, and eviscerated. Immediately after evisceration, lean meat percentage, longissimus dorsi muscle depth, and back fat thickness were estimated according to prediction equations generated by the software Hennessy System GP4 
after carcass scanning with an electronic probe. Afterwards, the carcass bonus index was calculated according to the processing plant standards.

\section{Statistical analysis}

The experimental period was divided into three (70 to $100 \mathrm{~kg}$ of BW, 100 to $130 \mathrm{~kg}$ of BW, and 70 to $130 \mathrm{~kg}$ of BW) for statistical analysis. Data were first tested for normality of studentized residuals and homogeneity of variances. Once these assumptions were reached, data were analyzed in a one-way ANOVA and in the case of significant differences, means were compared by SNK multiple-range test. All statistical procedures were performed in SAS software (SAS, 2004) and statistical significance was set at $P \leq 0.05$.

\section{Results and Discussion}

Organic $\mathrm{Cr}$ and Se supplementation did not affect final BW or daily weight gain between 70 and $100 \mathrm{~kg}$ of BW (Table 2). However, supplemented pigs reduced their daily feed intake $(P=0.008)$ and improved their feed conversion rate $(P=0.004)$ in comparison to the control group. Between 100 and $130 \mathrm{~kg}$ of BW, pigs that received $\mathrm{Cr}-$ and $\mathrm{Se}-$ enriched yeast supplementation from $100 \mathrm{~kg}$ of BW increased daily feed intake $(P=0.032)$ in comparison to the control group, but no difference in daily feed intake was detected between the control group and pigs that received organic $\mathrm{Cr}$ and Se from $70 \mathrm{~kg}$ of BW. Considering the whole experimental period (70 to $130 \mathrm{~kg}$ of BW), Cr- and Se-enriched yeast supplementation from $100 \mathrm{~kg}$ of BW increased daily feed intake in comparison to the control group.

The average temperature during the experimental period ranged from 20.9 to $33.5^{\circ} \mathrm{C}$ (Figure 1), thus indicating that on most days, pigs were submitted to a moderate to severe heat stress according to the thermal comfort zone of 15 to $21{ }^{\circ} \mathrm{C}$ established by Sampaio et al. (2004). This situation could partially explain the low feed intake observed here, particularly during the final period when pigs weighed more than $100 \mathrm{~kg}$ of BW. According to Kiefer et al. (2010), chronic heat stress reduces feed intake, body weight gain and impairs the feed conversion rate of finishing pigs. These responses are highly associated with the reduced capacity of pigs to dissipate heat through body surface in hot environments.

Bertechini (2006) stated that growingfinishing pigs might not improve weight gain after organic $\mathrm{Cr}$ and Se supplementation, because the associated increase in dietary metabolizable energy level reduces feed consumption. Indeed, when supplementing finishing barrows with 0.4 to $0.8 \mathrm{mg}$ $\mathrm{kg}^{-1}$ of Cr-enriched yeast and 0.3 to $0.6 \mathrm{mg} \mathrm{kg}^{-1}$ of Se-enriched yeast, Rodrigues (2016) did not find performance differences between supplemented and non-supplemented groups. Similarly, Matthews et al. $(2001,2005)$ found no effect of $0.2 \mathrm{mg} \mathrm{kg}^{-1}$ of $\mathrm{Cr}$ tripicolinate or $\mathrm{Cr}$ propionate supplementation on pig performance between 23 to $115 \mathrm{~kg}$ of BW. However, Peres et al. (2014) showed that $0.2 \mathrm{mg}$ $\mathrm{kg}^{-1}$ of $\mathrm{Cr}$ methionine supplementation improved the weight gain and feed conversion ratio of finishing pigs. Xu et al. (2017) also showed better feed conversion in swine supplemented with $\mathrm{Cr}$ methionine with or without $\mathrm{Zn}$ sulfate from 50 to 110 $\mathrm{kg}$ of BW. Comparing the effects of $0.3 \mathrm{mg} \mathrm{kg}^{-1}$ of Se protein and Se-enriched yeast, Jang et al. (2010) described better performance in pigs supplemented with the first additive, suggesting that Se protein has higher bioavailability to pigs than Se-enriched yeast. Differences in the bioavailability of organic $\mathrm{Cr}$ and $\mathrm{Se}$ between sources could be the reason for such discrepant results in the literature. 
Table 2. Performance of pigs supplemented with $\mathrm{Cr}$ - and Se-enriched yeast between 70 and $130 \mathrm{~kg}$ of body weight.

\begin{tabular}{lcccccc}
\hline \multicolumn{1}{c}{ Item } & Control & CrSe70 & CrSe100 & Mean & CV (\%) & $P$ value \\
\hline 70 to 100 kg of body weight & & & & & & \\
Initial body weight $(\mathrm{kg})$ & 66.24 & 66.05 & - & 66.17 & 2.45 & 0.837 \\
Final body weight $(\mathrm{kg})$ & 104.45 & 104.14 & - & 104.35 & 2.27 & 0.817 \\
Daily feed intake $(\mathrm{kg})$ & $3.50^{\mathrm{a}}$ & $3.20^{\mathrm{b}}$ & - & 3.40 & 4.77 & 0.008 \\
Daily weight gain $(\mathrm{kg})$ & 1.06 & 1.08 & - & 1.07 & 4.25 & 0.493 \\
Feed conversion rate $(\mathrm{kg} / \mathrm{kg})$ & $3.29^{\mathrm{b}}$ & $2.96^{\mathrm{a}}$ & - & 3.17 & 4.96 & 0.004 \\
\hline 100 to 130 $\mathrm{kg}$ of body weight & & & & & & \\
Initial body weight $(\mathrm{kg})$ & 103.78 & 104.14 & 105.12 & 104.35 & 2.30 & 0.672 \\
Final body weight $(\mathrm{kg})$ & 129.52 & 128.44 & 131.07 & 129.67 & 1.83 & 0.269 \\
Daily feed intake $(\mathrm{kg})$ & $3.21^{\mathrm{b}}$ & $3.31^{\mathrm{ab}}$ & $3.50^{\mathrm{a}}$ & 3.34 & 4.05 & 0.032 \\
Daily weight gain $(\mathrm{kg})$ & 0.83 & 0.77 & 0.83 & 0.81 & 6.99 & 0.670 \\
Feed conversion rate $(\mathrm{kg} / \mathrm{kg})$ & 3.92 & 4.29 & 4.24 & 4.16 & 9.19 & 0.305 \\
\hline 70 to $130 \mathrm{~kg}$ of body weight & & & & & & \\
Initial body weight $(\mathrm{kg})$ & 66.46 & 66.05 & 66.01 & 66.17 & 2.57 & 0.900 \\
Final body weight $(\mathrm{kg})$ & 129.52 & 128.44 & 131.07 & 129.67 & 1.83 & 0.269 \\
Daily feed intake $(\mathrm{kg})$ & $3.27^{\mathrm{b}}$ & $3.20^{\mathrm{b}}$ & $3.49^{\mathrm{a}}$ & 3.32 & 2.36 & 0.001 \\
Daily weight gain $(\mathrm{kg})$ & 0.94 & 0.94 & 0.97 & 0.95 & 3.01 & 0.158 \\
Feed conversion rate $(\mathrm{kg} / \mathrm{kg})$ & 3.53 & 3.45 & 3.63 & 3.54 & 4.89 & 0.318 \\
\hline
\end{tabular}

Control - basal diet without organic Cr and Se supplementation from 70 to $130 \mathrm{~kg}$ of body weight; CrSe 70 - basal diet supplemented with $\mathrm{Cr}$ - and Se-enriched yeast from 70 to $130 \mathrm{~kg}$ of body weight; $\mathrm{CrSe} 100$ - basal diet without organic Cr and Se supplementation from 70 to $100 \mathrm{~kg}$ of body weight, but supplemented with $\mathrm{Cr}$ - and Se-enriched yeast from 100 to $130 \mathrm{~kg}$ of body weight.

Values within a line with the same superscript do not differ significantly at $P \leq 0.05$ (SNK multiple-range test).

According to Lindemann et al. (2008), the bioavailability of $\mathrm{Cr}$ tripicolinate in comparison to $\mathrm{Cr}$ from propionate, enriched yeast and methionine for growing piglets was 13.1, 22.8 and $50.5 \%$, respectively. However, in a metaanalysis assembling results from 31 studies in which $\mathrm{Cr}$ was supplemented for growing-finishing pigs as complexes of $\mathrm{Cr}$ methionine chelate, $\mathrm{Cr}$ nanocomposite, $\mathrm{Cr}$ nicotinate, $\mathrm{Cr}$ propionate,
$\mathrm{Cr}$ tripicolinate, or Cr-enriched yeast, Sales and Jancik (2011) detected positive effects of $\mathrm{Cr}$ supplementation, irrespective of its source, on average daily gain and gain:feed ratio. No effect of Cr was detected on feed intake, though. Apparently, sex and age of the animals, in addition of source and level of inclusion of organic $\mathrm{Cr}$ and $\mathrm{Se}$, might have an impact on the extent of the response of pigs to these minerals. 
Figure 1. Daily variation of environmental temperature during the experimental period.

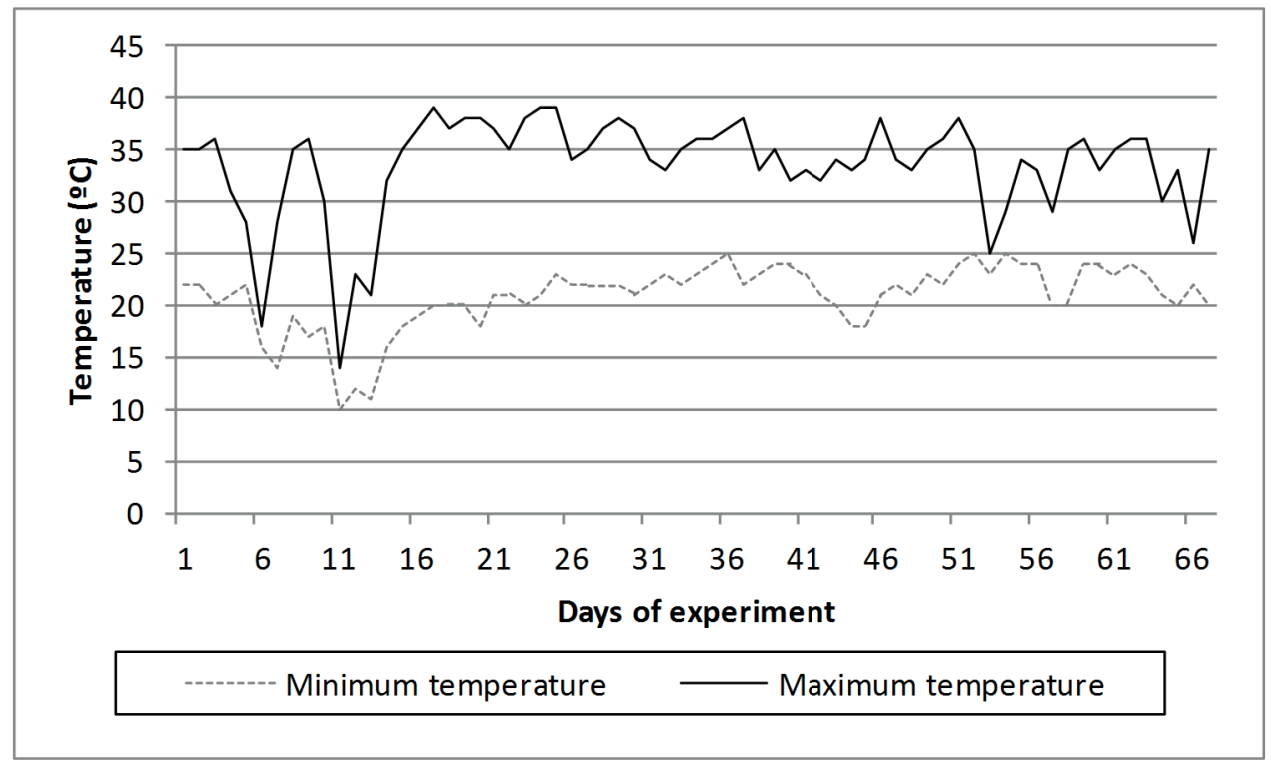

Organic $\mathrm{Cr}$ and $\mathrm{Se}$ supplementation increased $(P=0.019)$ longissimus dorsi muscle depth in both $\mathrm{CrSe} 70$ and $\mathrm{CrSe} 100$ treatments (Table 3). Nevertheless, lean meat percentage, back fat thickness and carcass bonus index were not affected by treatments. Increases of $17.1 \%$ (LIEN et al., 2001) and 7\% (WOLTER et al., 1999) in the loin eye area of finishing pigs supplemented with $\mathrm{Cr}$ picolinate or Se-enriched yeast were described previously. However, different to the results found here, a significant reduction in back fat thickness due to organic $\mathrm{Cr}$ and $\mathrm{Se}$ supplementation was also detected by the same authors (13.7 and 15\%, respectively). Moreover, Rodrigues (2016) and Stupka et al. (2012) described no effect of organic $\mathrm{Cr}$ and Se supplementation on carcass characteristics of finishing pigs.

Table 3. Carcass characteristics of pigs supplemented with $\mathrm{Cr}$ - and Se-enriched yeast between 70 and $130 \mathrm{~kg}$ of body weight.

\begin{tabular}{lcccccc}
\hline \multicolumn{1}{c}{ Item } & Control & CrSe70 & CrSe100 & Mean & CV (\%) & $P$ value \\
\hline Lean meat (\%) & 59.34 & 59.83 & 59.13 & 59.43 & 5.89 & 0.596 \\
Longissimus dorsi muscle depth (mm) & $69.15^{\mathrm{b}}$ & $73.34^{\mathrm{a}}$ & $72.34^{\mathrm{a}}$ & 71.66 & 8.85 & 0.019 \\
Back fat thickness (mm) & 15.66 & 16.37 & 17.61 & 16.52 & 27.36 & 0.099 \\
Carcass bonus index & 109.23 & 110.49 & 110.08 & 109.93 & 3.62 & 0.269 \\
\hline
\end{tabular}

Control - basal diet without organic $\mathrm{Cr}$ and Se supplementation from 70 to $130 \mathrm{~kg}$ of body weight; CrSe 70 - basal diet supplemented with $\mathrm{Cr}$ - and Se-enriched yeast from 70 to $130 \mathrm{~kg}$ of body weight; CrSe100 - basal diet without organic Cr and Se supplementation from 70 to $100 \mathrm{~kg}$ of body weight, but supplemented with Cr- and Se-enriched yeast from 100 to $130 \mathrm{~kg}$ of body weight. Values within a line with the same superscript do not differ significantly at $P \leq 0.05$ (SNK multiple-range test). 
Considering that $\mathrm{Cr}$ stimulates the uptake of both glucose and amino acids (GOMES et al., 2005), the rule of $\mathrm{Cr}$ on carcass muscle and fat deposition is probably a consequence of the increased availability of glucose to energy metabolism, sparing amino acids for protein synthesis. This could explain the greater longissimus dorsi muscle depth observed here after Cr- and Se-enriched yeast supplementation. Furthermore, as many discrepant results are found in the literature, one could speculate that factors such as the total period of supplementation, besides the source and the level of inclusion of organic $\mathrm{Cr}$ and $\mathrm{Se}$ in the diet, might influence the extent of pig responses to these minerals.

\section{Conclusions}

Dietary supplementation of Cr- and Se-enriched yeast for castrated male pigs between 70 and $130 \mathrm{~kg}$ of body weight increases longissimus dorsi muscle depth in the carcass without affecting the final body weight or daily weight gain.

\section{Acknowledgements}

The authors thank those in charge of the commercial farm for the use of facilities and experimental components. The first author also thanks the Graduate Program in Animal Science of the Federal University of Mato Grosso do Sul and CAPES/Brazil for granting a post-doctoral scholarship.

\section{References}

BERTECHINI, A. G. Nutrição de monogástricos. Lavras: UFLA, 2006. 301 p.

BRASIL. Portaria MAPA n ${ }^{\circ} 711$, de 01 de novembro de 1995. Diário Oficial [da] República Federativa do Brasil, Brasília, 1995. Seção 1, p. 17625.

BRUMATTI, R. C.; KIEFER, C. Simulação técnicoeconômica da inclusão de ractopamina em dietas de suínos em terminação. Arquivo Brasileiro de Medicina Veterinária e Zootecnia, Belo Horizonte, v. 62, n. 1, p.
163-171, 2010.

CAMPOS, P. F. Suplementação de vitamina E e selênio orgânico em dietas com ractopamina para suínos em terminação. 2013. Tese (Doutorado em Zootecnia) Universidade Federal de Viçosa, Viçosa, MG.

CENTNER, T. J.; ALVEY, J. C.; STELZLENI, A. M. Beta agonists in livestock feed: status, health concerns, and international trade. Journal of Animal Science, Champaign, v. 92, n. 9, p. 4234-4240, 2014.

CHIBA, L. I. Sustainable swine nutrition. Auburn: Wiley-Blackwell, 2013. 508 p.

GOMES, M. R.; ROGERO, M. M.; TIRAPEGUI, J. Considerações sobre cromo, insulina e exercício físico. Revista Brasileira de Medicina do Esporte, São Paulo, v. 11, n. 5, p. 262-266, 2005.

JANG, Y. D.; CHOI, H. B.; DUROSOV, S.; SCHEGEL, P.; CHOI, B. R.; KIM, Y. Y. Comparison of bioavailability of organic selenium sources in finishing pigs. AsianAustralasian Journal of Animal Sciences, Seoul, v. 23, n. 7, p. 931-936, 2010.

KIEFER, C.; MEIGNEN, B. C. G.; SANCHES, J. F.; CARRIJO, A. S. Resposta de suínos em crescimento mantidos em diferentes temperaturas. Archivos de Zootecnia, Córdoba, v. 58, n. 221, p. 55-64, 2009.

KIEFER, C.; MOURA, M. S.; SILVA, E. A.; SANTOS, A. P.; SILVA, C. M.; LUZ, M. F.; NANTES, C. L. Respostas de suínos em terminação mantidos em diferentes ambientes térmicos. Revista Brasileira de Saúde e Produção Animal, Salvador, v. 11, n. 2, p. 496504, 2010.

LIEN, T. F.; WU, C. P.; WANG, B. J.; SHIAO, M. S.; SHIAO, T. Y.; LIN, B. H.; HU, C. Y. Effects of supplemental levels of chromium picolinate on the growth performance, serum traits, carcass characteristics and lipid metabolism of growing-finishing pigs. Journal of Animal Science, Champaign, v. 72, n. 2, p. 289-296, 2001.

LINDEMANN, M. D.; CROMWELL, G. L.; MONEGUE, H. J.; PURSER, K. W. Effect of chromium sources on tissue concentration of chromium in pigs. Journal of Animal Science, Champaign, v. 86, n. 11, p. 2971-2978, 2008.

MARTINEZ-GOMEZ, N.; DOMINGUEZ-LÓPEZ, A.; JESÚS MORALES-ROSALES, E. de; LUGO, J.; MARIEZCURRENA-BERASAIN, M. A.; BERASAIN, M. D. M. Efecto de la levadura enriquecida con selenio y selenito de sodio en la dieta de cerdos en finalización sobre el contenido de grasa intramuscular y acidos grasos. Tropical and Subtropical Agroecosystems, Mérida, v. 15, n. 1, p. 41-46, 2012. 
MATTHEWS, J. O.; GUZIK, A. C.; LE MIEUX, F. M.; SOUTHERN, L. L.; BIDNER, T. D. Effects of chromium propionate on growth, carcass traits, and pork quality of growing-finishing pigs. Journal of Animal Science, Champaign, v. 83, n. 4, p. 858-862, 2005.

MATTHEWS, J. O.; SOUTHERN, L. L.; FERNANDEZ, J. M.; POINNTIF, J. E.; BIDNER, T. D.; ODGAARD, R. L. Effect of chromium picolinate and chromium propionate on glucose and insulin kinetics of growing barrows and on growth and carcass traits of growingfinishing barrows. Journal of Animal Science, Champaign, v. 79, n. 8, p. 2172-2178, 2001.

PERES, L. M.; BRIDI, A. M.; SILVA, C. A. D.; ANDREO, N.; BARATA, C. C. P.; DÁRIO, J. G. N. Effect of supplementing finishing pigs with different sources of chromium on performance and meat quality. Revista Brasileira de Zootecnia, Viçosa, MG, v. 43, n. 7, p. 369-375, 2014.

RODRIGUES, G. P. Suplementação de cromo e selênio orgânicos para suínos machos castrados dos 25 aos 110kg. 2016. Dissertação (Mestrado em Ciência Animal) - Universidade Federal de Mato Grosso do Sul, Campo Grande.

ROSTAGNO, H. S.; ALBINO, L. F. T.; DONZELE, J. L.; GOMES, P. C.; OLIVEIRA, R. F.; LOPES, D. C.; FERREIRA, A. S.; BARRETO, S. L. T.; EUCLIDES, R. F. Tabelas brasileiras para aves e suínos: composição de alimentos e exigências nutricionais. Viçosa, MG: UFV, 2011. $252 \mathrm{p}$.

SAKOMURA, N. K.; SILVA, J. H. V.; COSTA, F. G. P.; FERNANDES, J. B. K.; HAUSCHILD, L. Nutrição de ruminantes. Jaboticabal: FUNEP, 2014. 678 p.
SALES, J.; JANCIK, F. Effects of dietary chromium supplementation on performance, carcass characteristics, and meat quality of growing-finishing swine: a metaanalyses. Journal of Animal Science, Champaign, v. 89, n. 12, p. 4054-4067, 2011.

SAMPAIO, C. A. P.; CRISTANI, J.; DUBIELE, J. A.; FUBIELA, J. A.; BOFF, C. E.; OLIVEIRA, M. A. Avaliação do ambiente térmico em instalação para crescimento e terminação de suínos utilizando os índices de conforto térmico nas condições tropicais. Ciência Rural, Santa Maria, v. 34, n. 3, p. 785-790, 2004.

STATISTICAL ANALYSIS SYSTEM INSTITUTE SAS. Help and Documentation. SAS 9.1.3. Cary: SAS Institute Inc., 2004.

STUPKA, R.; CITEK, J.; SPRYSL, M.; BRZOBOHATY, L.; OKROUHLA, M.; KLUZAKOVA, E. The effect of organic selenium and the duration of its use on selected indicators of fattening capacity and carcass value in hybrid pigs. Research in Pig Breeding, Prague, v. 6, n. 1, p. 49-53, 2012.

WOLTER, B.; ELLIS, M.; MCKEIT, F. K.; MILLER, K. D.; MAHAN, D. C. Influence of dietary selenium source on growth performance, and carcass and meat quality characteristics in pigs. Canadian Journal of Animal Science, Ottawa, v. 79, n. 1, p. 119-121, 1999.

XU, X.; LIU, L.; LONG, S. F.; PIAO, X. S.; WARD, T. L.; JI, F. Effects of chromium methionine supplementation with different sources of zinc on growth performance, carcass traits, meat quality, serum metabolites, endocrine parameters, and the antioxidant status in growingfinishing pigs. Biological Trace Element Research, Clifton, v. 179, n. 1, p. 70-78, 2017. 
